\title{
Why has Widening Access to Tertiary, in South Africa, Not Resulted in Success?
}

\author{
Dr Phyllis Kaburise \\ English Department, University of Venda \\ phyllis.kaburise@univen.ac.za
}

\section{Doi:10.5901/mjss.2014.v5n20p1309}

\begin{abstract}
Widening access was a strategy aimed at transforming tertiary education to ensure that it was inclusive and could serve as a broad base for social redress. For this purpose, Higher Education introduced intervention measures aimed at facilitating access for students, representative of the country's demographics as well as their successful completion of their studies. However concerns become apparent when one balances the successes against the widened access. Twenty years into the expected transformation, issues such as, the extent of student under-preparedness, low retention and graduation rates, high unemployment levels of certain categories of tertiary graduates mean the idea of inclusiveness needs to be interrogated. The aim of this paper was to reflect on reasons why widening access has not resulted in academic success. This reflective paper shows that success has been negatively affected by endemic challenges arising from two sectors of the education system. These challenges were summarized as issues surrounding secondary schooling and policies and attitude of HEls, government and society to tertiary education. These concerns formed the focus of our discussions in the subsequent sections of the paper.
\end{abstract}

Keywords: Inclusive, tertiary, access, success, transformation

\section{Introduction and Background}

One feature of policy documents, after 1994, drafted by the National Commission on Higher Education (NCHE) was the mandate for the transformation of higher education so that South Africa can be responsive to the country's academic and social contexts ('Size and Shape' document, 2000; National Plan for Higher Education, 2001; New Academic Plan for Programmes in and Qualification in Higher Education, 2002). Running through these documents was the mandate for Higher Education Institutions (HEls) to transform in accordance with concerns about democracy, social justice, human rights and inclusiveness. One attempt at addressing these matters was to widen access to higher education, to ensure that HEls had staff and student patterns representative of the nation's demographics, and curriculum and policies which would foster inclusiveness (Waghid, 2003). Widening access was seen as creating conducive conditions for participation, and hopefully success, of a greater diversity of students, in tertiary education. This gave prominence to the twin notions of 'access and success' with the assumption that if access is designed appropriately, and implemented comprehensively, success would be the end product.

HEls did set in motion steps aimed at widening access to tertiary education. For instance, the total number of students increased from 473,000 in 1993 to 799,388 in 2008, to 837,779 in 2009. In 1993, 40\% of all students were African $(191,000)$ and $52 \%$ were black; by 2008 the numbers of Africans had risen to $64 \%(513,570)$ and black enrolment stood at $75 \%$ of all enrolment (Education Statistics, 2010). In addition the proportion of white students' enrolled shrunk from nearly half of the student population in 1993 to around $25 \%$ in 2008 indicating the increased presence of students from other racial groups (MacGregor, 2009). This improvement in access to education was not limited to South Africa. Over the past 50 years, access to higher education was seen not only as a way for nations to join in the race for globalisation and become part of the information world, but tertiary exposure was seen as also essential for national cohesiveness. The result was an open access policy model for tertiary seen in the fact that between 2000 and 2007, enrolment increased by 52 million tertiary students, worldwide (UNESCO 2009). South Africa and the rest of the world therefore see access to tertiary or an inclusive education agenda as a means of addressing social justice (Bates, 2007; Suarez-Villa, 2012).

The mandate to transform, therefore, has seen the introduction by HEls, on their own or through governmentinitiated strategies, ways to widen access to tertiary education, for those who otherwise would not have had the opportunity. These initiatives include re-examination of entrance requirements, reviews of curricula, recognition of priorlearning, introduction of intervention programmes, extending degrees and lately, plans to introduce 4year generic 
degrees. Access has also been made more inclusive through a massive injection of funds hence many financiallydisadvantaged students are supported by the National Student Financial Aid Scheme (NSFAS) which in 2008 provided grants to more than 125,000 students and in 2009 disbursed loans and bursaries worth R1.8 billion, double the amount awarded in 2007 (Education Statistics, 2010). This is in addition to special funds for scarce skills, bursaries from NGOs and industries. This amount is expected to increase over the years. Block and Earmarked grants to HEls have increased, from R5.2 billion in 1996 to R14.8 billion in 2008, to assist institutions accommodate the expected increase in academically diverse students.

Widening access, its resultant diversity of students and increase in government spending, however, has also generated some concerns. Among them are concerns about the quality (Akoojee, 2002; Akoojee \& Nkomo, 2007) and in particular whether access has, indeed increased the success rate. Higher Education Management Information System (HEMIS) figures of 2009, however confirm the unacceptable figures of the attrition levels in higher education. It has been established that, although attrition rates differ from institution to institution, especially between highly selective full time institutions and others like open and distance education institutions their levels may be as high as 50\% (Giannakopolous \& Buckley (2008). Figures also indicate that the undergraduate degree and diploma graduation rates from the 23 higher institutions range for (contact instruction) from 26\% (North West University) to 13\% (Mangosuthu University of Technology). University of Venda (UNIVEN) has a rate of 20\%; University of South Africa (distance instruction) shows a rate of $8 \%$. These percentages clearly indicate that the assumption of success being consequential to greater access needs to be re-examined.

\subsection{Statement of the problem}

Inclusive education is an attempt by many African countries to infuse issues of democracy, social justice and human rights into their societies. In South African, at the tertiary level, inclusive education has been attempted through the twin notions of 'access and success'. Nearly twenty years after intensive implementation of these notions, matters such as, high attrition rates, questions about quality, the call for a 4year generic bachelor's degrees and high percentage of unemployed/unemployable graduates mean that the notion of 'access and success' needs to be interrogated.

\section{Theoretical Framework}

The concept of inclusiveness is fundamentally premised on the assumption that resources of a country should be equitably distributed; one such resource which should be shared by all the citizenry is availability of education (Gerwit, 2002; Morrow, 2009). Inclusive education emphasises acceptance, promotion and participation of all calibre of learners and diversity of approaches to this goal (Pendlebury \& Enslin, 2004). Inclusiveness therefore, describes an education which addresses any form of oppression such as racism, sexism and heterosexism (Negash, Olusola, \& Colucci, 2011). Negash et al., (2011) envisage that inclusiveness would create a society in which individuals are both self-determining (able to develop their full capacities) and interdependent (capable of interacting democratically with others). An inclusive education is understood both as a process and goal that allows for the full and equal participation of all groups in a society that is mutually shaped to meet their needs. This model of education, South Africa has attempted to achieve, at tertiary, through the notions of access and success.

The term 'access' and its inherent activities originated in the 1960s and 1970s but assumed more momentum in the 1990s. There are two conceptions of access - 'access as participation' and 'access with success' - in the history of South African education. 'Access as participation' is concerned with strategies to widen inclusion of a diverse range of students, representative of the demographics of the country (Andrews, 2003). 'Access with success' stresses that mere participation of these students is not enough, but similar conducive conditions should be created to support these students throughout their studies. Conducive conditions would include drawing up and implementing of appropriate policies, injection of needed resources and certain transformations in the practices of stakeholders. Stress on 'access with success' was in response to the realization that increased participation, for example, of black students, from 13\% in 1993 to 39\% in 1999 had not translated into higher retention or increased graduation rates (Cloete \& Bunting, 2001). 'Access with success' then became a vital feature of inclusive education.

Inclusive education which falls within the theoretical framework of social justice is very comprehensive, ranging from the conservative, through liberalism to the radical. The conservative idea of social justice rests on the supporters' belief that for a society to be just, individuals self-interest and the motivation for profit, while operating under a laissezfaire economic policy, must assume a central position (Feser, 2005; Otsuku, 2005 in Tjabane \& Pillay, 2012). Liberalism is associated with issues of justice as 'fairness' and the theories of equality and freedom; similar to conservatism in its 
belief that social justice can be achieved within the existing capitalism. Liberalism differs in the sense that it favours the state as a responsible for society and regulators to ensure equitable distribution of resources (Schwartz, 2007; Tuckness, 2005). Radical social justice is leftist in character, advocating equitable participation in the socio-economic and political activities of a country. Transformation in this context involves visible redistribution of wealth and a society's emancipation and advances towards a utopian situation. This paradigm is in line with Young's 2000 identification of social justice being freedom from oppression, namely, violence, powerlessness, exploitation, marginalisation and cultural imperialism (in Tjabane \& Pillay, 2012). An education falling within the paradigm of inclusiveness would be demonstrated in aspects such as curricula, pedagogy, policies and practices culminating in quality and marketable outputs for the masses.

\section{Discussions}

South Africa has indeed attempted to provide inclusive tertiary education. For instance, an inclusive higher education has been implemented with a curricula that recognise the differential capabilities and interests of the students and hence the need for diversity of HEls' offerings. Evidence of this can be seen in the mergers of universities into three types, namely, traditional (eleven) (offering first and post-graduate degrees with strong research component), technology (six) (vocationally-oriented, offering certificates, diplomas and degree with some research activities) and comprehensive (six) (which combines the offerings of the other two institutions). These combined with the artisan training available in the further education and training colleges (FETs) have widen the education landscape for students. In addition, from the 1990s, South Africa further concretised its desire for an inclusive education by further introducing differential access routes into HEls by providing some kind of foundation supports for deserving students. Increasing participation across all population groups, in the form of strengthening students' base competencies, was the rationale behind providing the various supporting strategies - bridging, remedial, foundation, extended and the proposed 4year degrees. All are attempts at structuring an education which would cater for the masses. Support for financially-disadvantaged students, as discussed earlier has seen yearly increases in NSFAS which in 2009 disbursed loans and bursaries worth R1.8 billion (Education Statistics, 2010). In addition, South African tertiary institutions have recorded substantial growth in enrolment over the last ten years from 550000 in 2002 to 837000 in 2009. Since 2008, the Department of Higher Education and Training (DHET) in recognition of the increased demands on HEls infrastructure and administrative costs have increased block and earmarked grants to HEls.

These endeavours to offer an inclusive tertiary education is most commendable but concerns become apparent when one balances the successes against widened access. For instance, although the participation rate of 18-24 year olds in higher education had improved to $16.6 \%$ based on 2008 rates, these rates are not balanced racially; $60 \%$ of whites, $50 \%$ of Indians, $13.6 \%$ of coloureds and $12.8 \%$ of blacks are participating in tertiary studies (Higher Education in Context, 2012). In 2011, HESA noted 'Student success rate in the public Higher Education system illustrated the dysfunctionality of the system' (Parliamentary Monitoring Group, 2011). The question at this juncture is: Why is the system dysfunctional? It is the contention of this paper that the dysfunction is a result of endemic challenges relating to two sectors of the whole education system - issues surrounding secondary schooling and policies and attitude of HEls, government, and society to tertiary education. These concerns will be the focus of our discussions in the next sections.

\subsection{Issues surrounding secondary schooling}

The high level of student under-preparedness - a constant feature of tertiary education and a constant variable in high attrition and HEIs' inability to meet graduation and success targets - is the result of complex factors existing in the school system. These stem from teachers' poor pre-service training, lack of content knowledge and competence in the language of instruction, the lack of a wide spectrum of resources in the schools, the combined ill-effects of low socio-economic status of most rural children and the unreliable matriculation (matric) results. Kamper (2008) gives a detailed synopsis of what he terms "South African high-poverty schools". It is most worrying when one observes the level of teachers' lack of proficiency in content subjects as well as in the language of instruction, in most rural schools. Instances are narrated, constantly, of teachers (in Grades 10 -12 classrooms) using mother tongue to teach content subjects and even English. There are high schools which teach science without laboratories or even equipment hence students' first encounter with science equipment and experiments are at tertiary. It is not out of the ordinary, in an English major lecture class to revisit basic 'word classes' because a lecturer cannot expatiate on complex sentence constituents. The moments needed for this constant remedial and foundational intervention, for even mainstream students can only detract from the quality of degrees with which the graduates enter the job markets. Schools, and rural schools in particular are characterized by large classes, lack of teaching aids, inappropriate teaching strategies or what Kamper (2008) calls "drill and kill teaching 
or poverty pedagogics". This situation inculcates in high school classes certain learning styles - memorization, nonresearching skills, unquestioning acceptance of facts and lack of analytical skills - all learning habits, at odds with the critical and investigative nature of tertiary knowledge creation. In addition, a matric subject pass mark of $30 \%$, adding of extra marks for students from certain language-disadvantaged areas and provincial adjustment of marks aggravate and mask the extent of students' under-preparedness when they enter tertiary. A similar concern is voiced in the statement made during the meeting by the Parliamentary Monitoring Group (2011) "There was no point in celebrating the goal of the matric throughput, while ignoring the content". The debilitating effects of these high school teaching and learning practices have compelled all the intervention initiatives currently in place - bridging, remedial, foundation, extending and Academic Development (AD) programmes - to ensure that access results in success. Marked success has not been the result of these support strategies since performance levels are still below the National Plan for Teaching and Learning set standards. Only seven out of the $23 \mathrm{HEls}$ met the success requirements of $80 \%$. Black students represented $75 \%$ of enrolled students yet only $25 \%$ of these graduated in the stipulated time of their various degrees, with $45 \%$ of these enrolled students dropping out of the system (Parliamentary Monitoring Group, 2011). This obvious lack of gains from the support programmes has now necessitated a call for a 4 year generic bachelor degree.

Another reason access has also not fully yielded the desired results stems from the lack of synergy between the secondary and tertiary spheres of the education system. Foundation for tertiary studies is laid in the secondary schools therefore lecturers have a right to assume that base knowledge and competencies are in place when students enroll for degrees. Some of the detrimental consequences of this lack of synergy are the disqualification of students for noncompliance with pre-requisites for their careers of choice, such as potential accounting students who took mathematical literacy at high school level. The ambivalent position of the subject, Life Orientation (LO) is another point in the discussions. The usual excellent performance of students in this subject implies that it impacts substantially on students' final matric classification hence its non-recognition as a university entrance subject narrows as well as jeopardizes students' choices at tertiary. Situations of this nature also arise because most disadvantaged students are first generation scholars who cannot benefit either from discussions with educated families members and communities or informed career-guidance practitioners in their schools. It is however hoped that the Netherland Initiative for Capacity Development in Higher Education (NICHE) project of orientations and workshops on careers will provide some intervention. The situation, currently illustrates the urgent need for Departments of Basic and Higher Education, as well as HEls and high schools to have a common understanding of each other's curricula so that points of non-articulation and core requirements can be streamlined.

\subsection{Policies and attitude of HEls, government and society towards tertiary education}

South Africa has, as mentioned earlier, through the process of mergers categorized HEls into three types - traditional, technology and comprehensive. This categorization should manifest itself in also different practices, curricula and pedagogies, but this is not very obvious. Non-differentiation in practices in South Africa's three tier tertiary education system, poses a threat to the success of the ideals of access. Inclusiveness is analogous to diversity, for example, in terms of students' background, ambitions, careers, aptitude and the kind of support they may need. Differentiation in HEls and their offerings is likely to have minimum impact on success rates if necessary interventions arising from this diversity, such as application of appropriate practices and teaching styles are not put in place. HEls must identify niche areas in terms of their offerings and appropriate practices are then put in place. Suarez-Villa (2012) also talks of a three-tiered tertiary system where HEls are classified according to well-defined mandates and ways to implement them. The first tier offers a very open access policy, the second is more selective and the third extremely selective. The first tier which is in line with South Africa's current comprehensive institutions will offer degrees and training-enriched diplomas and certificates with strong local relevance. The open access policy of the first tier would mean that support initiatives like bridging courses, foundation provision and extended qualifications would be key features of such institutions. Here teaching/lecturing would be more appropriate. The second tier which has more selective admission requirements and is offering full-university qualifications in general and in some selected professional fields up to masters-graduate degrees would require a more reflective and critical approach to teaching and learning. Cutting-edge research and innovation would be the main characteristic of the third tier where independent investigative learning takes place.

Currently, the niche areas of the three categories of HEls are not well defined hence you have institutions attempting to be in all the three tiers and attracting students with diverse profiles. The tertiary landscape at the moment also points to students having minimum understanding or appreciation of the categorization. It is therefore, not unusual, at the beginning of every academic year, potential students, desperate at being rejected by institutions of their first preference, to walk into other institutions and to request for admission into any course which is not 'full'! The reading of 
this scenario is that students just desire to be in any HEl but whether an institution corresponds to their profile is immaterial. Yet one variable in a successful tertiary career is conformity between student and institution profiles, the very reason why Higher Education undertook the whole exercise of mergers. Hence, despite the differentiation in offerings, some students are still wrongly placed in their studies in terms of their profile. HEls then engage in de-personalised electronic teaching and learning styles, more appropriate in a third-tier institution, irrespective of the profile of their students. If there is an objective of increasing the success and graduation rates across the tiers, this would entail paying greater attention to the categorization of HEls.

Tacit acceptance of the non-significance of differentiation is obvious in DHET's continual support to HEls, irrespective of practices they are following. This is another determinant of poor retention and graduation percentages. Citing the need to respect HEls' autonomy and for them to be relevant to their immediate communities, DHET grants and funding for student support are not tied to institutions' adherence, for example, to issues of differentiation. Non-adherence to differentiation is, in addition, quite costly as HEls replicate sophisticated infrastructure across institutions which could have been avoided if HEls had their niche areas. For example, should comprehensive universities fully respond and transform to their mandates, forays into costly-infrastructure-intensive professions in science, engineering and technology (SET) would not be a priority, rather such HEls would be in established liaisons with FET colleges, professionalizing and sophisticating those type of artisan tertiary offerings. This type of relation has not been fully institutionlised also because of society's conception of higher education. FETs lack recognition as some students and parents see acceptable tertiary qualifications as only offered in universities. This fact, coupled with the lack of formalized articulation between HEls and FETs increases the non-acceptance of artisan training.

Inclusive education is explicit in the statement, 'Everyone has the right to education' (Article 26 of the Universal Declaration of Human Rights); however the declaration goes on to say '---higher education shall be equally accessible to all on the basis of merit' (Negash, Olusola \& Colucci, 2011). This declaration calls into question how far the government can mandate HEls to widen access to promote issues on social justice and human rights; tertiary education is not a panacea for all social ills. A crucial point being ignored here by the government - possibly from its yearning to be socially and politically correct or to be seen as following an agenda of redress of past ills - is that tertiary, as the third level in the system of education calls for considerable academic attributes and investment from students. Widening access should be implemented bearing in mind that 'a want' does not guarantee an ability to satisfy that want. Giannakopoulos \& Buckley (2008) articulate a similar moral dilemma when they ask the question "Accessing higher education: a right or a privilege?" In answering the question, they draw on both moral and pragmatic principles. They acknowledge that, morally, higher education should not be denied to any determined student with potential but equaling compelling is the fact that tertiary education is expensive for all stakeholders. Potential tertiary students, whatever other characteristic they may have, must have certain basic academic attributes; some are inculcated in them by well-grounded pre-tertiary schooling right from the pre-schools; some are inherent. Tertiary studies sophisticate all these attributes, culminating in confident, competent, qualified, professional and employable graduates. In other words tertiary education is not the initial point for building up of knowledge and competences; it is the maturing ground of such knowledge and competences. Using tertiary access as both an academic and societal levelling grounds is a one-sided approach to remedying entrenched structural disadvantages in South Africa. Studies by Kamper (2008), Taylor (2013) and Kaburise (2014) reiterate the already welldocumented educational advantages of socio-economic factors, hence anticipating considerable tertiary success from short term favourable access conditions at higher education level is rather 'too little, too late'. A similar point is made by HESA on the one year support initiatives at HEls "One year at university could not make up for 12 years of being disadvantaged" (Parliamentary Monitoring Group, 2011). Quality pre-tertiary schooling should be the starting place, although there is a suspicion that the massive investment that would be involved could be prohibitive. In a recent survey, there are 144122305 learners and students enrolled in all sectors of the education sector in 2009; of these only 837779 (5.9\%) are in HEls and 420475 (3\%) are in public FET institutions (Overview of the Education System in South Africa, 2012). With this picture, where approximately, $90 \%$ of learners are at pre-tertiary, it may seem logical, financially, that the focal point of remediation would be targeted at tertiary. The need to target interventions at this level may be lessened, however by the government's initiative to enforce a compulsory 2 year pre-schooling.

Widening access cannot be acknowledged as successful if employment of graduating students is not immediately available. Anticipation of life-improving employment is the strongest driving force behind parents' and students' preparedness to embark on tertiary students; for low socio-economic societies, this may be the only reason and not the acquisition of knowledge only for self-actualization. Unemployment rate at the moment is a vexing one. According to the Treasury Report of 2011, 51\% of the 18 - 24 cohorts are unemployed. Mda (2010) reports on a study by Bhorat et al., 2007 which notes that it is harder for African graduates to break into the employment world and they earn less than other race groups. The white unemployment rate is $14 \%$ and that of blacks $24 \%$ and total unemployment rate of Africans from 
historically white universities is lower than that of Africans from historically disadvantaged/black universities.

Generalisations about unemployment and joblessness are normally not very helpful as in some sectors there are acute shortages of manpower (Relations between Higher Education and the Labour Market, 2003; Cawood, 2009). The employment picture shows that there is a preference for skilled over semi-skilled or unskilled graduates; that is skilled for a particular job. For example, an English major graduate with excellent results would have no advantage competing for a job in human resources management. Global trends show a shortage of graduates in managerial, professional services and science, engineering and technology (SET) hence graduates in these areas are unlikely to face unemployment (MacGregor, 2012). This implies that parametres should govern open access to ensure South Africa does, within this notion, also achieve its stated purposes for Higher Education. Giannakopoulos \& Buckely (2008) summarise the South African White Paper (1997a) on the purposes as the development of the individual's learning needs and aspirations by developing their intellectual abilities and attitudes and to provide the labour market with high level competencies and expertise necessary for the growth and prosperity of a modern economy. Unemployable graduates hence defeat the purpose of Higher Education as well as the notion of access and success and rather create a dissatisfied citizenry. Access to be evaluated as successful, therefore must be compatible with the stated purposes of higher education.

\section{Conclusion}

South Africa's plans for transformation of higher education, through widening access have yielded successes by increasing participation of more diverse student population. Greater successes, however could have been achieved if certain endemic challenges to tertiary education are resolved. For example, the severity of the lack of preparedness and non-articulation between secondary and tertiary levels of education, policies and practices of government and HEls as well as societal conception of higher education have impacted adversely on the implementation of the purpose of access and success in Higher Education.

\section{References}

Akoojee, S. 2002. Access and quality in South African higher education: The challenges for transformation. Quality Conversations: Annual International Conference, Perth, Western Australia

Akoojee, S \& Nkomo, M. 2007. Access and quality in South African higher education: the twin challenges of transformation. South African Journal of Education 21 (3), 385-399

Bates, R. 2007. Education administration and social justice. Education, citizenship and social justice, 1(2) 141-156

Bhorat H, Visser, M. \& Mayet, N 2009. Student graduation, labour market destinations and employment earnings. In M Letseka, M Cosser, M Breier \& M Visser (eds): Student retention and graduation destination: Higher education and labour market access and success; (pp 97-123) HSRC Press.

Cawood, F. 2009. FETs not churning out suitable artisans for a sector that needs to mechanise faster. Mining Weekly

Cloete, N. \& Bunting I. 2001. Cross- National Indicators: A case study of eight African universities. Centre for Higher Education Transformation.

Department of Education. 1997. White Paper on Transformation (Community engagement)

Department of Education. 2010. Education Statistics in South Africa and Statistics South Africa population estimates.

Gerwitz, S. 2002. Plural concepts of social justice. Journal of Education, 17: 499-501

Giannakopoulos, A., Buckley, S. 2008. Accessing higher education. University of Johannesburg

Kamper, G. 2008. A profile of effective leadership in some South African high poverty schools. South Africa Journal of Education vol. 28 no. 1. Pretoria

Kaburise, P. 2014. Academic and socio-economic factors affecting literacy. (In print)

MacGregor, K. 2009. South Africa: Debate moves on from access to success. University World News.

MacGregor, K. 2012. Plan for 1.5 million students by 2030. University World News.

Mda, T. 2010. The structure and Entrenchment of Disadvantage in South Africa. Monash University Press.

Morrow, W. 2009. Bonds of democracy: epistemological access in higher education. Cape Town. HRSC Press.

NCHE. 1995. White Paper

NCHE. 2000. Size and Shape Document

NCHE. 2001. National Plan for Higher Education

NCHE. 2002. New Academic Plan for Higher Education.

NCHE. 2003. Relations between Higher Education and the Labour Market.

NCHE. 2012. In leaps and bounds: Growing higher education in South Africa. Higher Education in Context

Negash, Z., Olusola, O. \& Colucci, E. 2011. Access, participation and retention in Africa. Access to Success: Project Compendium

Pendlebury, S. \& Enslin, P. 2004. Social justice and inclusion in education and politics: the South African case. Journal of Education, 34: $31-51$ 
Schwartz, H.2007. Freedom, capitalism and religion. Retrieved from: wwwfreedomandcapitalism.com. 10 September 2008 Suarez-Villa, L. 2012. Educational access and massification. Regional inversion.

Taylor, S. 2012. How does socio-economic status impact on educational outcomes in South Africa? Unisa Press.

Tjabane, M. \& Pillay, V. 2012. Doing justice to social justice in South Africa higher education. Perspectives in Education, vol. 29 no. 29 , 10-18

Tuckness, A. 2005. Locke's political philosophy. Stanford encyclopaedia of philosophy.

University of Venda Strategic Plan. 2007.

Waghid, Y. 2003.Compassionate citizenship and higher education re-imaging. South Africa Journal of Higher Education, 17: 159-163 